\title{
Humor Creation Strategy in Political Communication of Indonesian Millenial Generation
}

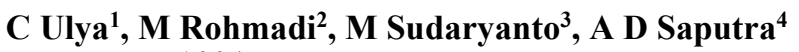 \\ 1,2,3,4 Universitas Sebelas Maret \\ 1․ㅡafit@staff.uns.ac.id, ${ }^{2}$ mamad_r76@staff.uns.ac.id, ${ }^{3}$ memetsudaryanto@staff.uns.ac.id, \\ 4aldidwisaputra@student.uns.ac.id
}

\begin{abstract}
Student demonstrations that took place in September 2019 presented new facts about political movements of students in Indonesia. In expressing their criticism, the students used unique dictions, tickling, and even tend to humor. From this background, an idea emerged to conduct a study of how the strategy of creating humor in the political communication of Indonesian millennial generation. This research is a type of qualitative research with a content analysis approach. A total of 30 data found were then analyzed using an interactive analysis model consisting of data collection, data reduction, data presentation, and verification or drawing conclusions. The results obtained from this study are that the strategy of creating humor on poster aspirations of students is pursued in two ways, namely through the exploration of themes and language games. At the thematic level, students related themes which were closely related to the surrounding teenage life, such as love, music, teenage lifestyle, pornography, and lecture activities. Meanwhile, aspects of language play found were dominated by sound similarities and metaphors.
\end{abstract}

\section{Keywords: Humor Creation Strategy, Humor, Political Commynication, Millennial Generation}

\section{INTRODUCTION}

Student demonstrations which took place in September 2019 presented new facts about political movements of students in Indonesia. Students as representatives of Indonesian millennial generation presented in a different view. Their critics no longer used sarcastic languages which tend to be rude, harsh, and to the point. Instead, they used unique dictions, tickling, and even tend to humor.

Illustration below shows the change in student political communication choices between events of the 1998 demonstrations and 2019.
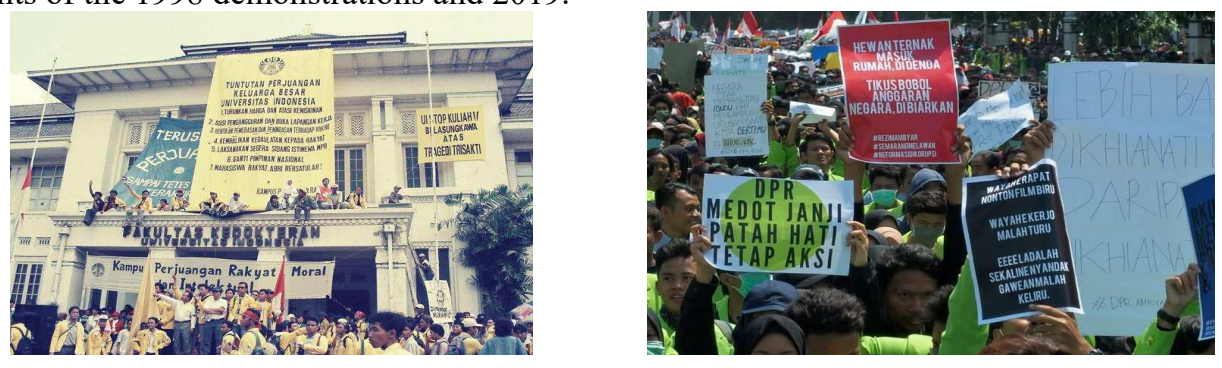
Figure 1 is a portrait of a student demonstration in 1998, meanwhile Figure 2 is one of the portraits taken from a student demonstration in 2019. We can compare the different dictions of the two images. The language used in Figure 1 tends to be straightforward and to the point, while Figure 2 shows the use of figurative language.

Here are examples to show the language change, such as

"Cukup cintaku saja yang kandas, KPK jangan!" ("Let only my love failed, don't let Commission of corruption Eradication failed too"), "Kirain hubungan kita aja yang gak jelas, ternyata DPR lebih gak jelas!" "'I thought our relationship is complicated, in fact, so is People's Representative Council"), ("The state does not facilitate our longing, but interferes in matters when we meet"), "DPR Medot Janji. Sumpahmu palsu koyo mantanku" ("People's Representative Council breaks its promise. Your faith is fake, like my ex's"), "Ke sini karna panggilan hati, bukan kebutuhan instastory" ("Coming here because of following our heart, not for the sake of instastory").

The tendency to use unique and tickling language - tends to lead to humor - is an interesting topic to study. The use of humor elements is a distinguishing characteristic of millennial generation aspirations from previous generations. Departing from this background, the idea emerged to conduct a study of how the strategy of creating humor in the political communication of Indonesian millennial generation.

Humor with various perspectives has been studied in a number of studies. Most of it is connected with fields that have comedy elements or funny things, such as humorous discourse in memes in online media [1], humorous discourse implicators in a speech title Talkshow on Net TV [2], presuppositions and implicatures on stand up comedy in Indonesia [3].

Meanwhile, in Indonesia there has not been much study of humor in relation to politics. In fact, in the broader realm, political humor is an interesting study that will attract society. One of several studies linking humor to politics was conducted by Kayam, Galily, \& Sover who highlighted the figure of Barack Obama. His research concluded that a leader who has a high sense of humor will have the ability to deal with difficult situations, have flexible thinking, have high social skills so that it will affect the people they lead [4].

Political humor and news from online media are effective tools for increasing political participation of young people [5]. Consuming sarcastic political humor can indirectly increase the potential for political participation in criticizing various government policies [6]. In addition, humor is also a means to convey an absurd reality that is faced and far from the expectations imagined [7].

Various studies of humorous discourse indicate that humor has an important function in human life. According to Dananjaja, humor has four functions, namely (1) as a means of social protest; (2) as an educational tool; (3) as a means of entertainment; (4) as a medium to improve morals [8]. Language play is a form of language variation in the context of carrying out its function as a means of social control so that the wider community can enjoy it. Humor as a form of language play becomes absolutely necessary as a means of social criticism [9].

\section{RESEARCH METHOD}

This research is a type of qualitative research with a content analysis approach. "Content analysis is a research technique for making replicable and valid inferences from texts (or other meaningful matters) to the context of their use" [10]. This research produces data in the form of 
written words [11]. The research data in the form of written words were taken from demonstration posters used by the students. A total of 30 data were found and then analyzed using interactive analysis models consisting of data collection, data reduction, data presentation, and verification or drawing conclusions [12].

\section{RESULTS AND DISCUSSION}

In creating humor on demonstration posters, there were two strategies used by students, namely through the exploration of themes and language games. The choice of themes close to the lives of millennials was the most widely used tool to bring up humor. These themes included love, music and songs, adolescent lifestyles, pornography, online games, to themes around lectures. Meanwhile, language games were also carried out to produce the humor in the poster, namely through rhyme and metaphor.

Among the themes that have been mentioned above, love was the most explored theme to be a means of political communication of millennial generation. The matters about love fail, relationships were not clear, or a sensitive heart was used as an irony of the nation's condition. Then, sentences were produced like "Cukup cintaku yang kandas, KPK jangan!" ("Let only my love failed, don't let Commission of corruption Eradication failed too"), "Kirain hubungan kita aja yang nggak jelas, ternyata DPR lebih nggak jelas." ("I thought our relationship is complicated, in fact, so is People's Representative Council"), "Aku kira yang lemah cuma hatiku, ternyata KPK juga" (I thought it's only my heart which not strong, in fact so is KPK”), etc

Music themes and songs were also widely explored by students. Some used fragments of song lyrics, some used title, others use Indonesian-language pop songs, and some pick up Javanese dangdut songs (campursari). There are several examples of expressions used, such as "DPR! Setan apa yang merasukimu?" ("DPR! What devil has possessed you?) taken from Ilir7 song, "Pak opo salah rakyatmu iki / Koe nganti tego mblenjani janji" ("Sir, what is wrong with your people / How come you have broken your promise") adopted from the song" Cidra " by Didi Kempot, "Itu DPR apa lagunya Afgan? Kok "SADIS" Is it DPR or is the song Afgan? How come "SADIST" was adopted from the title song Afgan, and etc.

Furthermore, the lifestyle of today's millennial adolescents is synonymous with the culture of santuy (enjoy), mager (lazing), watching drakor (Korean drama), running, playing online games, and so on are also widely explored. Some examples of sentences tell the life of this teenager include "Asline mager pol, tapi piye meneh? DPR-e pekok!!" ("Honestly I am lazy af, but what can I do? The DPR is dumb af"), "DPR udah kayak Drakor, banyak Drama" ("DPR has been like Korean drama, full of drama"), "Mabarku tak tinggal timbang negoroku ambyar" ("I left my hanging out with friends cause I dont want my country destroyed"), "Mahalnya Skin Care-ku tak semahal harga NKRI-ku" ("My skin care is expensive but my country is priceless"), "Tak pikir iki POCHINKI, jebule gedunge tukang korupsi" ("I thought it is POCHINKI, in fact this is place for curruption"), etc.

The theme of pornography is also quite common is expressions "Jangan biarkan alat produksi kami tidak beroperasi" ("Do not let our reproduction system stop working"), "Kurangi bekerja, perbanyak bercinta" ("Work less, make love more"), "Mia Khalifa wes tobat, Lha kok DPR malah kumat" ("Mia Khalifa is repent, why the parlement is recurent). In addition to the above themes, there are also those who express their feelings when lecturing in expressions "Cukup skripsi yang direvisi RUU KPK jangan!!!” (“Only my thesis is revised, not the KPK's regulations"), "Kuliahku tenanan, DPR malah dolanan” ("I study hard but representative concil just play around). 
Second, humor creation strategies are carried out through language games. Many language games to create humor are the sound similarities (rhyme) and the use of metaphors. Some examples of the use of sound equations are "Tak pikir iki POCHINKI, jebule gedunge tukang korupsi" ("I thought it is POCHINKI, in fact this is place for curruption"), "Negara tidak memfasilitasi rindu, tapi mencampuri urusan saat kita bertemu" ("The state does not facilitate our longing, but interferes in matters when we meet"),, "Kuliahku tenanan, DPR malah dolanan" ("I study hard but representative concil just play around). The sentences show the wording of rhyming words, namely the word 'pochinki' with 'corruption', the word 'rindu' by 'bertemu', and the words 'tenanan' and 'dolanan'. Sound similiarities has certain effects that are able to give or evoke responses to the thoughts and feelings of readers as commonly found in poetry [13].

In addition to the sound similarities, many metaphorical forms are found in the media of student aspirations, such as "Gedung ini jadi warung pecel" ("This building is a Pecel shop"), "Tak pikir iki POCHINKI, jebule gedunge tukang korupsi" ("I thought it is POCHINKI, in fact this is place for curruption"), "Cukup cintaku yang kandas, KPK jangan!" ("Let only my love failed, don't let Commission of corruption Eradication failed too" ). The metaphor that likens the council building like a Pecel stall is a satire carried out by students. Pecel stall is identified as a place where people can eat and relax together with friends and relatives. Therefore, students think that the DPRD building also has the same function for board members. In the DPRD building members of the council can eat and relax without thinking about the obligations that must be done. Metaphor is an effective means to express dislike towards something [14].

In addition to the form of sound and metaphorical similarities, language games that are mostly done by students can also be seen from the many uses of acronyms and abbreviations, especially acronyms related to adolescent lifestyles. Some of the acronyms used are mabar (hanging out), drakor (Korean drama), mager (lazy to move), and so on. Indeed the world of adolescents today, is blooming with the use of acronyms whose numbers are increasing day by day, such as bucin (slaves of love), gamons (failed to move on), gercep (fast movements), and so on. The use of this acronym also colors the course of student demonstrations. By Rahardi, the use of this acronym is seen as a symbol of innovation and language creativity [15].

In the other side, the humor creation strategy at this demonstration has become an oasis in the midst of the phenomenon of hate speech. Hate speech that is believed to cause social inequality, intolerance, and loss of humanism values [16] can be reduced by this humor. Humor is an effort to eliminate bad perceptions about demonstrations that tend to use blasphemous or insulting words that tend to be rude which impact on the growth of ignorance characters [17]. This is also in line with the concept conveyed by Pranowo that there are many ways by which speakers can deliver a message so that the communicative effects that arise can reach the speech partners, including stating cynically and stating insinuously [18].

In addition to being able to reduce tension due to the rise of hate speech, the use of humor in this demonstration also proves that open criticism is considered irrelevant. Humor media, such as stand-up comedy, memes, songs, satire jokes, and so on are no less important to convey criticism. In fact, these satire critics are seen to have better abilities in reaching and responding to political phenomena by utilizing unexpected means and Mans [19]. Through humor, the millennial generation of Indonesia responds to the political situation that occurs. Millennials who tend to be apolitical are able to respond to social and political issues with a typical youthful communication style that is enjoy, humorous, and full of satire messages [20].

However, on the other hand, the phenomenon of humor must also be seen from the perspective of its effectiveness in declaring aspirations. Humor does have many functions. Some consider this humor as entertainment, but sometimes, people can also be infuriated, hateful, 
insulted, and even offended by this humor [21]. However, according to Lesmana, political humor in Indonesia functions more as entertainment than criticism [22]. Then what about humor in student demonstrations? In order to answer this question, a deeper study needs to be done. Do not let this phenomenon of humor be limited to the need for a virus, as seen in one of the posters brought by students, "Kesini karna panggilan hati, bukan kebutuhan instastory" ("Coming here because of following our heart, not for the sake of instastory").

\section{CONCLUSIONS}

Based on the results discussed above, it can be concluded that the strategy of creating humor on poster students aspirations is pursued in two ways, namely through the exploration of themes and language games. At the thematic level, students relate themes that are closely related to the surrounding teenage life, such as love, music, teenage lifestyle, pornography, and lecture activities. Meanwhile, aspects of language play that are found are dominated by sound similarities and metaphors. The use of humor in student political communication is indeed in line with the mindset of millennial who tend to be enjoy, humorous, and full of poetic messages. However, further studies still need to be done to see the effectiveness of humor used in relation to social criticism.

\section{REFERENCES}

[1] A. Listiorini, "Wacana Humor dalam Meme di Media Online sebagai Potret Kehidupan Sebagian Masyarakat Indonesia," Litera, vol. 16, no. 1, pp. 64-77, 2017.

[2] N. Irfansyah and Sumarlam, "Implikatur Wacana Humor Gelar Wicara Ini Talkshow di Net TV," Bahastra, vol. 3, no. 1, pp. 49-57, 2017.

[3] A. Wijayanti, "Preposisi dan Implikatur pada Stand Up Comedy Indonesia," Transformatika, vol. 12, no. 2, pp. 46-59, 2016.

[4] O. Kayam, Y. Galily, and A. Sover, "Humor, Media, and The Oublic Discourse: A Case Study of Humor and Politics," French J. Media Res., 2013.

[5] A. B. Becker, "Political Humor as Democratic Relief? The Effects of Exposure to Comedy and Straight News on Trust and Efficacy," Atl. J. Commun., vol. 11, no. 5, pp. 235-250, 2011.

[6] H. Lee and N. Kwak, "The Affect Effect of Political Satire: Sarcastic Humor, Negative Emotions, and Political Participation," Mass Commun. Soc., vol. 17, no. 3, pp. 307328, 2014.

[7] L. Panke, "Polintertainment: The use of humour in political communication," Sphera Pública, vol. 13, no. 1, pp. 2-18, 2013.

[8] J. Danandjaja, Humor Mahasiswa. Jakarta: Pustaka Sinar Harapan, 2002.

[9] I. D. P. Wijana and M. Rohmadi, Analisis Wacana Pragmatik: Kajian Teori dan Analisis. Surakarta: Yuma Pustaka, 2009.

[10] K. Krippendorff, Content Analysis: An Introduction to Its Methodology (second edition). 2004.

[11] S. J. Taylor and R. Bogdan, Introduction to Qualitative Research Methods, 3rd ed. New York: John Wiley \& Sons, 1998.

[12] M. Miles and A. Huberman, "Miles and Huberman Chapter 2," in Qualitative Data Analysis, 1994.

[13] S. A. Sayuti, Berkenalan dengan Prosa Fiksi. Yogyakarta: Gama Media, 2000. 
[14] C. Ulya, N. E. W, and Y. Mujiyanto, "MUATAN PENDIDIKAN ANTIKORUPSI DALAM MATA KULIAH PENGKAJIAN DAN APRESIASI PUISI DI JAWA TENGAH DAN YOGYAKARTA," Indones. Lang. Educ. Lit., 2016.

[15] R. K. Rahardi, Bahasa Prevoir Budaya. Yogyakarta: Pinus Book Publisher, 2009.

[16] Irawan, "Hate Speech di Indonesia: Bahaya dan Solusi," Mawa'izh J. Dakwah dan Pengemb. Sos. Kemanus., vol. 9, no. 1, pp. 1-17, 2018.

[17] K. Laksono, "Ketidaksantunan Berbahasa di Lingkungan Pendidikan dan Dampaknya dalam Pembentukan Karakter," in Prosiding Seminar Nasional "Ketidaksantunan Berbahasa dan Dampaknya dalam Pembentukan Karakter," 2014, pp. 42-48.

[18] Pranowo, Berbahasa secara Santun. Yogyakarta: Pustaka Pelajar, 2012.

[19] R. P. Wadipalapa, "Meme Culture \& Komedi-Satire Politik: Kontestasi Pemilihan Presiden dalam Media Baru," J. IImu Komun., vol. 12, no. 1, pp. 1-18, 2015.

[20] W. P. Utomo, "Menertawakan Politik: Anak Muda, Satire, dan Parodi dalam Situs Mojok.co," J. Stud. Pemuda, vol. 4, no. 1, pp. 195-205, 2015.

[21] M. Rohmadi, "Strategi Penciptaan Humor dengan Pemanfaatan Aspek-aspek Kebahasaan," Humaniora, vol. 22, no. 3, pp. 285-298, 2010.

[22] M. Lesmana, "Teks-teks Humor Politik di Indonesia: Sekedar Hiburan atau Sekaligus Kritikan?,” J. Kaji. Sej. Pendidik. Sej., vol. 2, no. 1, pp. 91-100, 2014. 